\title{
DOWNY WILLOW (Salix lapponum L.) AS A COMPONENT OF DIFFERENT PHYTOCOENOSES IN POLESIE NATIONAL PARK
}

\author{
Magdalena Pogorzelec \\ Department of General Ecology, University of Life Sciences, Akademicka 15, 20-950 Lublin, Poland \\ e-mail: magdalena.pogorzelec@up.lublin.pl
}

Received: 11.09.2008

\begin{abstract}
The aim of this study was to make an evaluation of the current stands of a relict species, Salix lapponum, within the area of the Polesie National Park, to determine the population size and condition of downy willow as well as to analyse biocenotic conditions in its stands.

The study, conducted in the years 2001-2003, allowed to establish that the number of S. lapponum stands had decreased significantly and that its population size in the confirmed stands in the Polesie National Park was substantially lower than 50 years ago.

Salix lapponum was a component of different phytocoenoses, but its highest population size and a high degree of development were noted at the sites with the Betulo-Salicetum repentis and Thelypteridi-Phragmitetum communities. The character of the phytocoenoses in which Salix lapponum occurred in greatest numbers may evidence the wide range of tolerance of downy willow with respect to habitat conditions.

There is a probability that not only the changes in its habitat conditions, which were noted over the last half-century, had a significant effect on the reduction in the number of stands and in the population size of this species. An essential problem appears to be the fact of the absence of flowering in individuals in many of the studied populations, which may result in an insufficient degree of adaptation of $S$. lapponum to changing habitat conditions
\end{abstract}

Key words: Salix lapponum, Polesie National Park, phytocoenoses, change in population size

\section{INTRODUCTION}

The Polesie National Park (with an area of 9647.73 ha) was established in 1990 in order to protect the aquatic-bog ecosystems. The Park is located in the central part of the Łęczyńsko-Włodawskie Lakeland (the Polesie Lubelskie Region), where hydraulic improvements of this area, related to the construction of the Wieprz-Krzna Canal, had been carried out since the 50's of the 20th century. Alongside grassland (about $\left.665 \mathrm{~km}^{2}\right)$ and arable land $\left(380 \mathrm{~km}^{2} ; \mathrm{M} \mathrm{i} \mathrm{c} \mathrm{h} \mathrm{a} 1\right.$ c zyk, 1991), the peatlands, being the habitat for boreal flora, were also included in the drained land. Changes in water relations in this area disturbed the water discharge rate, resulting in the absence of water stagnation (C h mi e lew s k i and R a d w a n, 1993), and the allochthonous water conveyed through the Canal, characterised by different trophism and chemical composition, contributed to the change in habitat conditions (Wilgat, 1991; Michalczyk and Tu r c z yńs ki , 1998; T u r c z y ńs ki et al. 2000).

In connection with the intensification of anthropopressure, the habitats of many species of the relict boreal flora became fragmented in the area in question, which contributed to a drastic decline in their population size until the time of the establishment of the Polesie National Park. Downy willow (Salix lapponum) was also among the abovementioned, extremely valuable species.

Salix lapponum is a common species in the peatlands of the subarctic-boreal areas of Eurasia; it also grows at detached sites in Scotland as well as in some mountains of Central and Southern Europe (K a c, 1975; B olliger et al.1998; P odbielk ow ski, 2002). The south-western limit of the species range runs through the territory of Poland ( $\mathrm{Krusze} \mathrm{ln} \mathrm{i-}$ c ki , 2001).

The largest number of lowland stands of this species in Poland has been preserved in the Polesie Lubelskie Region, within the area of the Łęczyńsko-Włodawskie Lakeland (F i j a k o w s k i, 1996; S ołty s and Różycki, 1996; Fij a ł k ow s ki and Lorens, 1998; Wojciechowski and Fijałkowski, 1998; Urban and W a wer, 2001; Fijałkow ski and I z d e b s ki, 2002; N o w i c k a - F a l k ow s ka, 2002; U r b a nd Gaw lik, 2003).

In its natural stands in the ŁęczyńskoWłodawskie Lakeland, S. lapponum grows on fens 
and transitional bogs, among the communities of the class Scheuchzerio-Caricetea fuscae, sporadically - of the order Molinietalia; sometimes it encroaches into Betulo-Salicetum repentis birch thickets. Downy willow shoots usually grow individually or in small groups (F i j a k k o w sk i, 1994; F i ja łk o w sk i and Lorens, 1998).

The reasons for the decline in Salix lapponum population size and the reduction in the number of its natural stands in Poland are mainly attributed to the changes in habitat conditions related to drainage and succession processes at its sites $(\mathrm{J}$ a s now ska and Jasnowski, 1977; Podbielkowski and Tomaszewicz, 1977; Kruszelnicki, 2001; Piękoś-Mirkowa and Mirek, 2003).

The aim of this study, conducted in the years 2001-2003, was to make an evaluation of the current stands of this species within the area of the Polesie National Park, to determine the current population size of Salix lapponum and the characteristics of biocenotic conditions in the habitats of this species.

\section{MATERIALS AND METHODS}

The field study was carried out in the Polesie National Park in the years 2001-2003. The first stage of the study (in 2001) involved the exploration of the area on foot and site visits of the downy willow stands known from literature (F i j a ł k o w s k i, 1958; Chmielewski et al. 1995; Wojciechowski and F i j a k k ow s k i, 1998). In the confirmed S. lapponum stands, permanent study plots of different size were established (from 4 to $400 \mathrm{~m}^{2}$ ). Their selection was based on the location, distribution and different population sizes of downy willow within the study area, as linked to biocenotic variations in the habitats.

In total, 8 study plots were set up: two ( $\mathrm{N}^{\circ} 1$, 2) on the peat bog surrounding Lake Moszne (in the $\mathrm{W}$ and $\mathrm{N}$ parts of the bog); two ( $\left.\mathrm{N}^{\circ} 3,4\right)$ on the peat bog adjacent to the eastern shore of Lake Długie (in the S and S-E parts of the bog); three $(5,6,7)$ on the peat bog adjacent to Lake Karaśne (in the S-E and E parts of the bog); one study plot (8) on the mid-forest peat bog "Blizionki" (in the western part of the bog) in the complex "Orłowskie Bagno" (marsh) (Fig. 1).

Each year, the number of Salix lapponum individuals on each study plot was determined, measurements were made of the length of the above-ground parts of shoots as well as the development degree (condition) of individuals was determined using an original, comparative, three-level classification of shoot condition, which took into account the characteristic habit and the general health condition of plants:

1. A fully-developed plant, sparsely foliated, slender, a significant amount of dry or wilted leaves, with symptoms of activity of pathogens or pests.
2. A fully-developed plant, fruiting or flowering, with symptoms of wilting or activity of pathogens, but growing properly.

3. A fully-developed plant, fruiting or flowering, with standard morphometric traits (i.e., consistent with the data in R utk ow ski 1998), correctly growing, with dense foliage, no disease or wilting symptoms.

The quantitative ratio of female to male individuals was also documented (in the flowering period, at the turn of March and April 2003).

In 2002 the condition of the phytocoenoses in the study plots was documented by making and analysing floristic lists which included the percentage shares of particular species in the studied phytocoenoses.

The species occurring in the investigated phytocoenoses were identified using the key of Rutkowski (1998), species nomenclature followed Mire k et al. (2002), the assignment of particular species to syntaxonomic units followed $\mathrm{Ma}$ t u s z k i e w i c z (2005). During office investigations, Ecological indicator values of vascular plants of Poland ( $\mathrm{Z}$ a r z y c k i et al. 2002) was also used to determine specific habitat conditions, based on the affinity of plant species of particular phytocoenoses with characteristic ecological groups, as well as Jaccard's formula (Wy socki and Sikorski, 2002) in order to calculate the index of species similarity between particular phytocoenoses in which $S$. lapponum occurred. The probability index value may be within the range from 0 to 1 , where 0 means the lack of similarity between the phytocoenoses, whereas 1 means one hundred percent similarity of the species composition.

\section{RESULTS}

During the exploration of the study area on foot, the following Salix lapponum stands were confirmed on the peat bogs located within the Polesie National Park: on Moszne Lake (Fig. 2), Karaśne Lake, Długie Lake as well as on the mid-forest bog "Blizionki". No other stands of this species known from literature were found (Tab. 1).

The investigated downy willow populations in the Polesie National Park were generally characterised by their small population size. S. lapponum occurred in greatest numbers on the peat bogs on Karaśne and Moszne Lakes, where an increase in the number of shoots was additionally noted over the successive three years of study, as well as the best condition of the investigated specimens. The largest decline in population size of the studied species was noted at the site on Długie Lake, where the condition of the specimens was also the poorest. The flowering of $S$. lapponum was noted in the population living on Długie Lake (only 
Table 1

The number of S. lapponum specimens' comparison in its stands in Polesie National Park - 1950's and present state.

\begin{tabular}{lll}
\hline \multicolumn{1}{c}{ S. lapponum stands in PPN } & \multicolumn{1}{c}{ S. lapponum occurrence in 1950's* } & \multicolumn{1}{c}{$\begin{array}{c}\text { S. lapponum occurrence } \\
\text { in 2001-2003 }\end{array}$} \\
\hline Moszne & about 1000 specimens & about 100 individuals \\
\hline Długie & about 2000 specimens & abort 50 individuals \\
\hline N-E Długie Lake & conglomeration over 100 shrubs & unconfirmed station \\
\hline Karaśne & conglomeration about 10 shrubs & about 60 individuals \\
\hline Blizionki & conglomeration about 10 shrubs & $4-5$ individuals \\
\hline Lukie & conglomeration 10-50 shrubs & unconfirmed station \\
\hline Wąskie (presently Bagno Wąskie) & conglomeration about 10 shrubs & unconfirmed station \\
\hline Bagno Staw & conglomeration about 10 shrubs & unconfirmed station \\
\hline
\end{tabular}

* information included as a description in text and on the map; names 'specimens' and 'shrubs' according to original (Fijałkowski 1958)

Table 2

Salix lapponum on plots in Polesie National Park.

\begin{tabular}{|c|c|c|c|c|c|c|c|c|c|}
\hline \multirow{2}{*}{$\begin{array}{c}\text { Stations } \\
\text { Plots }\end{array}$} & \multirow[t]{2}{*}{ Year } & \multicolumn{2}{|c|}{ Moszne } & \multicolumn{2}{|c|}{ Długie } & \multicolumn{3}{|c|}{ Karaśne } & \multirow{2}{*}{$\begin{array}{c}\text { Blizionki } \\
8\end{array}$} \\
\hline & & 1 & 2 & 3 & 4 & 5 & 6 & 7 & \\
\hline \multicolumn{2}{|l|}{ Plot's size $\left(\mathrm{m}_{c}\right)$} & 20 & 100 & 100 & 100 & 10 & 400 & 144 & 4 \\
\hline \multirow{3}{*}{ Number of shoots } & 2001 & 13 & 30 & 46 & 5 & 9 & 33 & 11 & 5 \\
\hline & 2002 & 4 & 30 & 26 & 5 & 10 & 39 & 12 & 5 \\
\hline & 2003 & 8 & 34 & 8 & 5 & 6 & 47 & 8 & 4 \\
\hline \multirow[t]{3}{*}{ Max. height of shoots (cm) } & 2001 & 50 & 50 & 85 & 40 & 40 & 70 & 60 & 39 \\
\hline & 2002 & 50 & 50 & 30 & 30 & 60 & 50 & 55 & 40 \\
\hline & 2003 & 55 & 50 & 30 & 25 & 50 & 70 & 50 & 45 \\
\hline \multirow[t]{3}{*}{ Individual condition (1-3) } & 2001 & 2 & 3 & 1 & 2 & 2 & 3 & 2 & 2 \\
\hline & 2002 & 1 & 3 & 1 & 2 & 2 & 3 & 2 & 2 \\
\hline & 2003 & 1 & 3 & 1 & 2 & 2 & 3 & 2 & 2 \\
\hline $\begin{array}{l}\text { Ratio of female to male } \\
\text { blooming shoots }+: \bigcirc^{\nearrow}\end{array}$ & & $?$ & $?$ & $1: 0$ & $?$ & $0: 1$ & $3: 1$ & $?$ & $?$ \\
\hline
\end{tabular}

male individuals) and on Karaśne Lake (both male and female individuals; Tab. 2).

Based on the floristic lists of the phytocoenoses of each study plot, it was found that the phytocoenosis of study plot $\mathrm{N}^{\circ} 2$, located on the peat bog on Moszne Lake, was characterised by the greatest species richness (39 species), whereas the lowest number of vascular plant species was recorded within the boundaries of study plot $\mathrm{N}^{\circ} 8$ (on the peat-bog Blizionki - 13 species; Tab. 3).
Vascular plant species most frequently co-occurring with Salix lapponum in its stands were as follows (in alphabetic order): Betula pubescens, Carex rostrata, Comarum palustre, Lysimachia vulgaris, Menyanthes trifoliata, Oxycoccus palustris and Thelypteris palustris. The botanical family Cyperaceae was represented in the greatest number in the phytocoenoses with downy willow (14 species; Tab. 3 ).

Species characteristic for the syntaxonomic classes Phragmitetea and Scheuchzerio-Caricetea ni- 
Table 3

Floristic composition of phytocoenoses with Salix lapponum in Polesie National Park, included syntaxonomic view and percent participation of each plant species ('+' single individuals).

\begin{tabular}{|c|c|c|c|c|c|c|c|c|}
\hline \multirow{2}{*}{$\begin{array}{l}\text { Stations } \\
\text { Plots }\end{array}$} & \multicolumn{2}{|c|}{ Moszne } & \multicolumn{2}{|c|}{ Długie } & \multicolumn{3}{|c|}{ Karaśne } & \multirow{2}{*}{$\begin{array}{c}\text { Blizionki } \\
8\end{array}$} \\
\hline & 1 & 2 & 3 & 4 & 5 & 6 & 7 & \\
\hline Number of vascular plants & 30 & 39 & 26 & 26 & 26 & 25 & 24 & 13 \\
\hline Layer a density $(\%)$ & 10 & 1 & - & - & - & - & - & - \\
\hline Layer b density (\%) & 50 & 40 & - & 1 & 20 & 60 & 60 & 10 \\
\hline Layer c coverage $(\%)$ & 80 & 60 & 90 & 70 & 90 & 50 & 50 & 60 \\
\hline Layerd coverage $(\%)$ & 90 & 90 & 60 & 90 & 90 & 80 & 100 & 100 \\
\hline \multicolumn{9}{|c|}{ Cl. Phragmitetea } \\
\hline Calla palustris & & & & & + & & & \\
\hline Carex acutiformis & 20 & 30 & & 30 & 50 & & & + \\
\hline Carex appropinquata & 10 & 30 & & & 20 & & & \\
\hline Carex elata & & & & & & & + & \\
\hline Carex pseudocypeus & 20 & & & & & & & \\
\hline Carex rostrata & 20 & 10 & 10 & & + & 10 & 10 & 60 \\
\hline Carex vesicaria & & & & & 10 & & & \\
\hline Equisetum fluviatile & & & + & + & 20 & 10 & 10 & \\
\hline Lysimachia thyrsiflora & & & + & + & & & & \\
\hline Peucedanum palustre & + & 10 & + & 10 & & + & & \\
\hline Phragmites australis & & 10 & 70 & 20 & & & & \\
\hline Ranunculus lingua & & & & & & + & + & \\
\hline Typha angustifolia & 20 & 20 & & & & & 10 & \\
\hline \multicolumn{9}{|c|}{ Cl. Scheuchzerio-Caricetea nigrae } \\
\hline Carex davalliana & 10 & 30 & & & & + & & \\
\hline Carex echinata & + & & & & & + & & \\
\hline Carex flava & & 10 & & & & & + & \\
\hline Carex limosa & & + & & & & & + & \\
\hline Carex nigra & & & 20 & 10 & & & & \\
\hline Comarum palustre & 20 & 20 & + & + & + & 10 & 20 & + \\
\hline Eriophorum angustifolium & & & + & + & & & & \\
\hline Epipactis palustris & & + & & & + & + & & \\
\hline Juncus articulatus & + & & & & & & & \\
\hline Menyanthes trifoliata & & 20 & 20 & 10 & + & + & & + \\
\hline Scheuscheria palustris & + & & & & & & & \\
\hline Triglochin palustre & & + & & & & & & \\
\hline Viola palustris & + & + & & + & & & 10 & \\
\hline & Cl. Oxy & $\operatorname{co}-\mathrm{S}$ & hagn & & & & & \\
\hline Andromeda polifolia & + & + & & + & & & & \\
\hline Drosera rotundifolia & 10 & 10 & + & + & + & + & + & \\
\hline Eriophorum vaginatum & + & & + & & + & & + & 20 \\
\hline Oxycoccus palustris & 40 & 60 & 40 & 50 & 30 & 30 & 30 & 40 \\
\hline & Cl. Molin & Arrh & nath & etea & & & & \\
\hline Carex panicea & & & 20 & & & + & & \\
\hline Cirsium palustre & & + & & & + & 10 & + & \\
\hline Epilobium palustre & & & & & + & & & + \\
\hline Galium uliginosum & + & + & & + & + & + & & \\
\hline Lysimachia vulgaris & 10 & + & 20 & 10 & + & 10 & 20 & \\
\hline Lythrum salicaria & + & + & + & & + & + & + & \\
\hline Molinia coerulea & & + & & & & & & \\
\hline Ranunculus acris & & + & + & & & & & \\
\hline Sanguisorba officinalis & & & & & & + & & \\
\hline & Cl. $A l$ & ea $g l$ & tinos & & & & & \\
\hline Alnus glutinosa & & & & & & 20 & 20 & \\
\hline Betula humilis. b & & & & + & 20 & 60 & 20 & + \\
\hline Calamagrostis canescens & 20 & + & + & & 30 & & & \\
\hline Salix cinerea $\mathbf{b}$ & 30 & 30 & + & & & & & \\
\hline Salix rosmarinifolia $\boldsymbol{b}$ & + & 10 & + & 10 & + & & & \\
\hline Salix aurita b & & 10 & & & + & & + & \\
\hline Salix pentandra $\mathbf{b}$ & + & + & & & & & & \\
\hline Thelypteris palustris & 80 & 40 & 30 & 20 & 20 & 30 & + & + \\
\hline & & $r \operatorname{spe}$ & & & & & & \\
\hline Betula pendula $\mathbf{b}$ & & + & & 10 & & & & \\
\hline Betula pubescens $\mathbf{a}$ & 50 & 30 & & & & & & \\
\hline Betula pubescens $\boldsymbol{b}$ & & + & 10 & 20 & 20 & 10 & 20 & 10 \\
\hline Dactylorhiza incarnata & & + & & + & & & & \\
\hline Frangula alnus $\mathbf{b}$ & 10 & 10 & + & 10 & & 10 & 20 & + \\
\hline Pleurozium schreberi $\mathbf{d}$ & & 30 & 40 & & & & & \\
\hline Pinus sylvestris a & & 10 & & & & & & \\
\hline Pinus sylvestris $\boldsymbol{b}$ & & 10 & & + & & & & \\
\hline Polytrichum strictum $\mathbf{d}$ & & & 10 & 20 & & & & \\
\hline Potentilla erecta & & & & & & + & + & \\
\hline Salix lapponum b & + & 10 & + & + & + & + & + & + \\
\hline Salix myrtilloides $\mathbf{b}$ & + & & & & & & & \\
\hline Sphagnum sp. d & 90 & 70 & 90 & 60 & 90 & 80 & 100 & 100 \\
\hline Stratiotes aloides & 10 & & & & & & & \\
\hline Utricularia vulgaris & & & & & 10 & & & \\
\hline
\end{tabular}


Table 4

Species similarity (by Jaccard's formula) between particular phytocoenoses in plots (1-8).

\begin{tabular}{cccccccc}
\hline Plots & $\mathbf{2}$ & $\mathbf{3}$ & $\mathbf{4}$ & $\mathbf{5}$ & $\mathbf{6}$ & $\mathbf{7}$ & $\mathbf{8}$ \\
\hline $\mathbf{1}$ & 0,59 & 0,35 & 0,36 & 0,38 & 0,35 & 0,31 & 0,27 \\
$\mathbf{2}$ & & 0,42 & 0,57 & 0,42 & 0,35 & 0,37 & 0,24 \\
$\mathbf{3}$ & & 0,52 & 0,37 & 0,39 & 0,35 & 0,35 \\
$\mathbf{4}$ & & & 0,37 & 0,37 & 0,25 & 0,34 \\
$\mathbf{5}$ & & & & 0,42 & 0,41 & 0,44 \\
$\mathbf{6}$ & & & & & 0,53 & 0,40 \\
$\mathbf{7}$ & & & & & & & \\
\hline
\end{tabular}

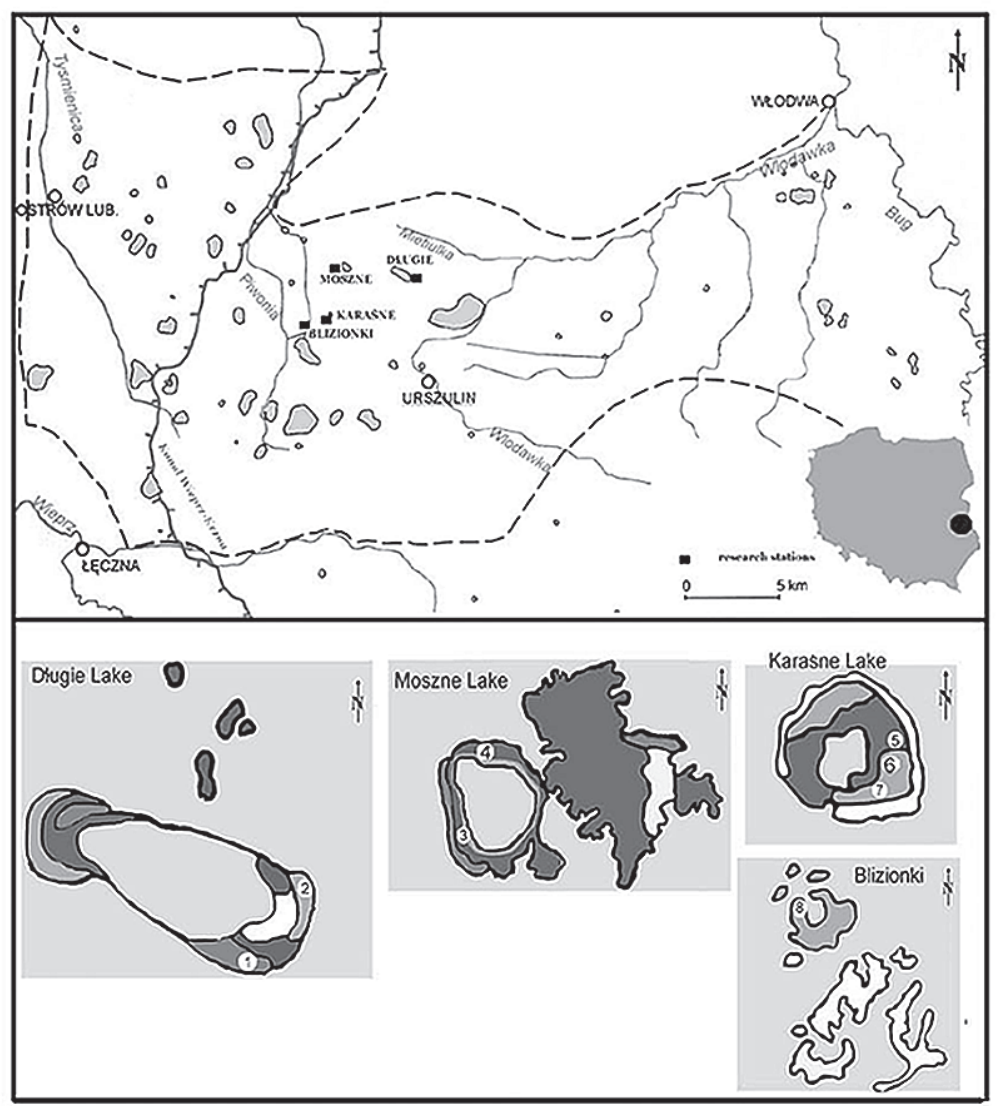

Fig. 1. Plots location on peat-bogs of Łęczna-Włodawa Lakeland (in Polesie National Park).

gre co-occurred most frequently with Salix lapponum. Based on the floristic lists and the quantitative characteristics of the phytocoenosis components, it can be stated that the study plots situated on Lake Długie and Lake Moszne were most similar in floristic terms to the community Thelypteridi-Phragmitetum; on Lake Karaśne - Caricetum acutiformis (plot № 5) and Bet-
ulo-Salicetum repentis (plots $\mathrm{N}^{\circ} 6$ and 7), whereas on the peat bog Blizionki - Caricetum rostratae (Tab. 3 ).

The index of species similarity of the studied phytocoenoses (according to Jaccard) ranged between 0.24 and 0.59 , but the largest similarity was demonstrated between plots $\mathrm{N}^{\circ} 1$ and 2 , which are located on the same peat bog on Lake Moszne (Tab. 4). 
Table 5

Percentage of plant species with different habitat requirements in plots' phytocoenosis (using the ecological indicator values of vascular plants).

\begin{tabular}{|c|c|c|c|c|c|c|c|}
\hline \multirow{2}{*}{ Selected indicators } & \multirow{2}{*}{ Plots } & \multicolumn{6}{|c|}{ Indicator values } \\
\hline & & 1 & 2 & 3 & 4 & 5 & 6 \\
\hline \multirow{8}{*}{$\mathrm{L}$ - light value } & 1 & 0 & 3,4 & 17,2 & 82,8 & 13,8 & 0 \\
\hline & 2 & 0 & 2,9 & 14,2 & 97,1 & 8,6 & 0 \\
\hline & 3 & 0 & 4,3 & 17,4 & 91,3 & 8,7 & 0 \\
\hline & 4 & 0 & 3,8 & 15,4 & 96,1 & 11,5 & 0 \\
\hline & 5 & 0 & 4,2 & 16,7 & 95,8 & 0 & 0 \\
\hline & 6 & 0 & 4,2 & 16,7 & 91,6 & 4,2 & 0 \\
\hline & 7 & 0 & 4,4 & 13,0 & 91,3 & 4,4 & 0 \\
\hline & 8 & 0 & 8,3 & 25,0 & 91,6 & 8,3 & 0 \\
\hline \multirow{8}{*}{$\mathrm{T}$ - temperature value } & 1 & 0 & 17,2 & 82,8 & 96,5 & 0 & 0 \\
\hline & 2 & 0 & 17,1 & 77,1 & 94,3 & 0 & 0 \\
\hline & 3 & 0 & 26,1 & 86,9 & 96,5 & 0 & 0 \\
\hline & 4 & 0 & 23,1 & 84,6 & 96,1 & 0 & 0 \\
\hline & 5 & 0 & 25,0 & 83,3 & 95,8 & 0 & 0 \\
\hline & 6 & 0 & 20,8 & 83,3 & 95,8 & 0 & 0 \\
\hline & 7 & 0 & 34,8 & 78,3 & 95,6 & 0 & 0 \\
\hline & 8 & 0 & 33,3 & 83,3 & 83,3 & 0 & 0 \\
\hline \multirow{8}{*}{$\mathrm{K}$ - continentality value } & 1 & 0 & 0 & 100 & 0 & 0 & 0 \\
\hline & 2 & 0 & 2,9 & 100 & 2,9 & 0 & 0 \\
\hline & 3 & 0 & 0 & 100 & 0 & 0 & 0 \\
\hline & 4 & 0 & 0 & 96,1 & 7,7 & 0 & 0 \\
\hline & 5 & 0 & 0 & 95,8 & 4,2 & 0 & 0 \\
\hline & 6 & 0 & 0 & 95,8 & 4,2 & 0 & 0 \\
\hline & 7 & 0 & 8,7 & 91,3 & 4,4 & 0 & 0 \\
\hline & 8 & 0 & 0 & 91,6 & 8,3 & 0 & 0 \\
\hline \multirow{8}{*}{$\mathrm{W}$ - soil moisture value } & 1 & 0 & 0 & 0 & 37,9 & 96,5 & 6,9 \\
\hline & 2 & 0 & 2,9 & 11,4 & 48,6 & 82,8 & 8,6 \\
\hline & 3 & 0 & 8,7 & 39,1 & 91,3 & 8,7 & 0 \\
\hline & 4 & 0 & 3,8 & 11,5 & 53,8 & 88,5 & 7,7 \\
\hline & 5 & 0 & 0 & 0 & 33,3 & 91,6 & 12,5 \\
\hline & 6 & 0 & 0 & 8,3 & 41,6 & 66,6 & 8,3 \\
\hline & 7 & 0 & 0 & 13,0 & 34,8 & 86,9 & 8,7 \\
\hline & 8 & 0 & 0 & 8,3 & 25,0 & 100,0 & 8,3 \\
\hline \multirow{8}{*}{$\mathrm{TR}$ - trophy value } & 1 & 13,8 & 13,8 & 72,4 & 41,4 & 0 & 0 \\
\hline & 2 & 11,4 & 22,8 & 74,3 & 42,8 & 0 & 0 \\
\hline & 3 & 4,3 & 26,1 & 73,9 & 47,8 & 0 & 0 \\
\hline & 4 & 15,4 & 30,8 & 80,8 & 34,6 & 0 & 0 \\
\hline & 5 & 12,5 & 16,7 & 70,8 & 45,8 & 0 & 0 \\
\hline & 6 & 8,3 & 20,8 & 75,0 & 45,8 & 0 & 0 \\
\hline & 7 & 13,0 & 30,4 & 65,2 & 43,5 & 0 & 0 \\
\hline & 8 & 16,6 & 41,6 & 66,6 & 41,6 & 0 & 0 \\
\hline \multirow{8}{*}{$\mathrm{R}$ - soil (water) acidity $(\mathrm{pH})$ value } & 1 & 17,2 & 24,1 & 41,4 & 44,8 & 20,7 & 0 \\
\hline & 2 & 17,1 & 20,0 & 40,0 & 62,8 & 25,7 & 0 \\
\hline & 3 & 17,4 & 30,4 & 47,8 & 60,8 & 8,7 & 0 \\
\hline & 4 & 19,2 & 26,9 & 53,8 & 57,7 & 11,5 & 0 \\
\hline & 5 & 12,5 & 20,8 & 37,5 & 62,5 & 16,7 & 0 \\
\hline & 6 & 12,5 & 25,0 & 45,8 & 62,5 & 16,7 & 0 \\
\hline & 7 & 17,4 & 30,4 & 43,5 & 56,5 & 13,0 & 0 \\
\hline & 8 & 25,0 & 41,6 & 58,3 & 41,6 & 0 & 0 \\
\hline \multirow{8}{*}{$\mathrm{H}$ - organic matter content value } & 1 & 3,4 & 13,8 & 96,5 & 0 & 0 & 0 \\
\hline & 2 & 11,4 & 37,1 & 82,8 & 0 & 0 & 0 \\
\hline & 3 & 0 & 26,1 & 95,6 & 0 & 0 & 0 \\
\hline & 4 & 7,7 & 26,9 & 96,1 & 0 & 0 & 0 \\
\hline & 5 & 0 & 20,8 & 95,8 & 0 & 0 & 0 \\
\hline & 6 & 0 & 29,2 & 95,8 & 0 & 0 & 0 \\
\hline & 7 & 8,7 & 30,4 & 91,3 & 0 & 0 & 0 \\
\hline & 8 & 0 & 8,3 & 100 & 0 & 0 & 0 \\
\hline
\end{tabular}




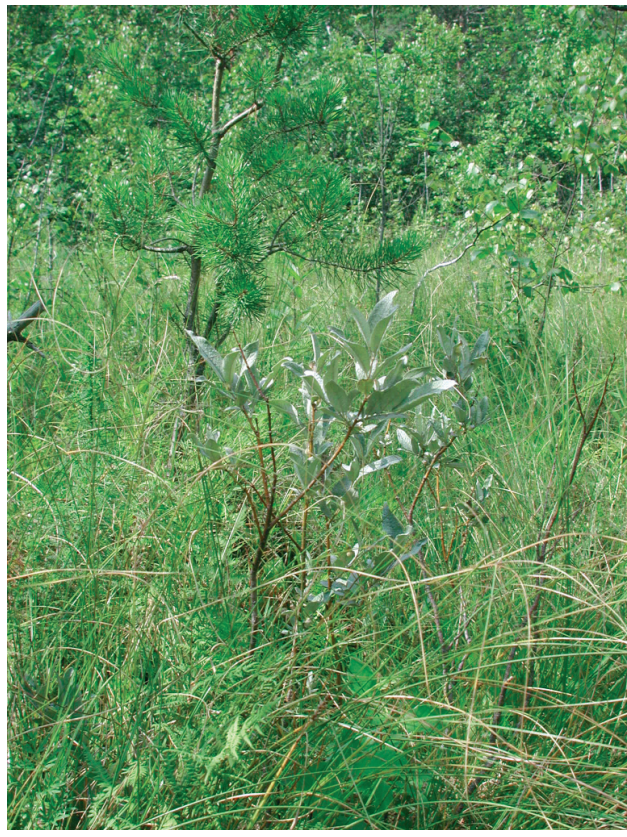

Fig. 2. Salix lapponum on the peat-bog near Lake Moszne in Polesie National Park.

An analysis of the flora, made using ecological indicator values ( $\mathrm{Zarzycki}$ et al. 2002), demonstrated that, in the phytocoenoses of all the study plots, species neutral to continentality were predominant, characteristic for areas with moderately cool or moderately warm climatic conditions, preferring moderate light at their sites. There was a predominance of plant species characteristic for wet and humid habitats, moderately poor soils (mesotrophic) with the neutral or moderately acid reaction of the substrate, as well as species encountered on organogenic soils (Tab. 5).

\section{DISCUSSION}

In 1958 D. Fijałk ow ski wrote that downy willow was a species frequently occurring in the Łęczyńsko-Włodawskie Lakeland. He described this species as one growing on peatlands in the form of single individuals or clusters composed of several, several dozen or even several hundred shrubs on relatively small patches which were often not more than several hundred square meters in area (Fijałkowski, 1958).

The original study carried out in the Polesie National Park in the years 2001-2003 showed that the number of stands and the population size of downy willow in this area had drastically decreased. Most of the stands known in the 1950's do not exist any more, whereas those which have survived until now are less densely populated. Sites in which this species occurs in clusters of several hundred shrubs are not currently encountered in this area. The absence of flowering of specimens in five out of the eight populations was also noted; therefore, unfortunately, an increase in population size cannot be expected.

Based on a comparison of the results of the 2001-2003 study with the data from the 1950's (Fijałkowski, 1959), it can be stated that many sites meeting the habitat requirements of Salix lapponum have been changed irrevocably over the last 50 years. The bog ecosystems have become overgrown as a result of accelerated succession or have been drained and radically changed their biocenotic structure. Salix lapponum has been preserved only at the sites in which habitat conditions have not changed to a large extent or at those in which such changes are taking place more slowly.

Biocenotic conditions at the Salix lapponum stands were characterised by Fijałkowski in the 1950's based on the floristic lists made by him. The synthesis of these results allowed him to find that the development of downy willow was the most abundant basically in the communities similar to the Caricion fuscae alliance (original nomenclature), where the investigated species reached an optimum of its development. Salix lapponum reached the upper limit of its ecological amplitude in eutrophic and relatively dry habitats, in the communities with the Molinion coeruleae alliance (original nomenclature), and its lower limit in oligothrophic and humid habitats, in the Rhynchosporion albae alliance (original nomenclature; Fijałk ow ski, 1958).

Urban and Wawer (2001) described the conditions of occurrence of Salix lapponum within the area of the Sobibór Landscape Park. The studied species occurred there in mid-forest transitional bogs and on difficult-to-access lake shores. Downy willow grew in the associations Caricetum lasiocarpae, Caricetum limosae, Sphagno-Caricetum rostratae, Betulo-Salicetum repentis and Salicetum pentandro-cinereae.

The results of my own study conducted in the years 2002-2003 showed that Salix lapponum was a component of different plant associations. Downy willow specimens in the phytocoenoses similar in their character to the communities Betulo-Salicetum repentis and Thelypteridi-Phragmitetum were distinguished by the largest population size and a high degree of development.

Betulo-Salicetum repentis is a phytocoenosis with distinctly boreal-continental character, whereas Thelypteridi-Phragmitetum is probably a succession stage, depending on habitat conditions, leading to very different alder carr, turf-bog and raised-bog associations, (Matuszkiewicz, 2005; Wysocki and Sikorski, 2002). 
The species composition of the phytocoenoses with downy willow was characterised (during the study conducted in the years 2001-2003) by a large share of species typical for wet, mesotrophic habitats, with soils rich in organic matter, with the reaction of the substrate ranging between 5 and $7 \mathrm{pH}$, as well as for habitats with moderate light. Downy willow (according to $\mathrm{Zarzycki}$ et al. 2002) prefers in its habitat similar abiotic conditions as other species of vascular plants accompanying it.

The results of the analysis of the study plots' flora confirm the results of the investigation of abiotic factors in the downy willow habitats. Downy willow occurs in the Łęczyńsko-Włodawskie Lakeland at waterlogged sites (where the water level reaches up to 10 $\mathrm{cm})$, mesotrophic, with the water $\mathrm{pH}$ ranging from 4.16 up to 6.17 (P o g o r z e le c, 2008).

The character of the phytocoenoses in which Salix lapponum occurred in greatest numbers may evidence the rather wide amplitude of habitat requirements of this species relative to other species of peat bog plants as well as it may prove that downy willow is a species which may participate in different succession stages. In the light of such conclusions, one may presume that it is not only habitat conditions that currently affect negatively the development of the downy willow population. It seems that intra-population processes also affect the continually deteriorating condition of this species' population within the study area.

\section{CONCLUSIONS}

- The number of S. lapponum stands has decreased significantly, and its population size in the confirmed stands in the Polesie National Park is substantially lower than 50 years ago.

- The condition and size of particular downy willow populations in the Polesie National Park vary, but based on the information about the absence of flowering of individuals in most of the studied sites, a significant increase in this species' population cannot be expected.

- The species composition of the phytocoenoses with Salix lapponum is characterised by a large share of species characteristic for wet, mesotrophic habitats, with soils rich in organic matter, with the reaction of the substrate ranging between 5 and $7 \mathrm{pH}$, as well as for habitats with moderate light, hence, with habitat requirements similar to those of downy willow.

- Salix lapponum is a component of different phytocoenoses, but its largest population size and its best condition were noted at the sites of the communities similar to Betulo-Salicetum repentis and Thelypteridi-Phragmitetum. The character of the phytocoenoses in which Salix lapponum occurs in greatest numbers may evidence the wide amplitude of requirements of downy willow with respect to habitat conditions and the participation of this species in different succession stages.

- Not only changes in habitat conditions, which were noted over the last half-century, probably have a significant effect on the decrease in the number of stands and species population size, but the lack of possibility of sexual reproduction may also play an important role, and what follows, the poorer adaptation of individuals to changing environmental conditions.

\section{REFERENCES}

Bolliger, Erben, Grau, Heubl. 1998. Krzewy. Leksykon przyrodniczy. Świat Książki, Warszawa.

Chmielewski T. J., Radwan S. 1993. Zmiany stosunków ekologicznych w rejonie Poleskiego Parku Narodowego w ostatnich 75 latach. / Changes in ecological relationships in the Polesie National Park area over the last 75 years. In: Radwan S., Karbowski Z., Sołtys M. (ed.). Ekosystemy wodne i torfowiskowe w obszarach chronionych. Materiały konferencji „Funkcjonowanie ekosystemów wodnych i torfowiskowych w obszarach chronionych". / Aquatic and bog ecosystems in protected areas. Materials from the conference "The functioning of aquatic and bog ecosystems in protected areas", Krasne 28 - 29 July 1993 TWWP, PPN, Lublin: 13-25.

Chmielewski T. J., Sielewicz B., Butrym I. 1995. Zmiany strukturalne i funkcjonalne ekosystemów jeziornych na tle zmian struktury ekologicznej rejonu Poleskiego Parku Narodowego w ciągu ostatnich 40 lat. / Structural and functional changes of lake ecosystems against the background of changes in the ecological structure of the Polesie National Park area over the last 40 years. In: Radwan S. (ed.), Ochrona ekosystemów wodnych w Poleskim Parku Narodowym i jego otulinie. Wyd. TWWP, Lublin: 96-107.

Chmielewski T. J., Sielewicz B., Holuk J. 2000. Ochrona przyrody. / Nature conservation. In: Chmielewski T. J. (ed.). Międzynarodowy Rezerwat Biosfery „Polesie Zachodnie”. PPN, Lublin: 97-100.

Fijałkowski D. 1958. Badania nad rozmieszczeniem i ekologią wierzby lapońskiej (Salix lapponum) na Pojezierzu Łęczyńsko-Włodawskim. / Studies on the distribution and ecology of downy willow (Salix lapponum) in Łęczyńsko-Włodawskie Lakeland. Fragm. Flor. Geobot. 3 (2), 89-103.

Fija łkowski D. 1959. Szata roślinna jezior i przylegających do nich torfowisk. / The vegetation cover of lakes in the Łęczna and Włodawa area and of peat bogs adjacent to these lakes. Ann. UMCS, sect. B, 14: 131-206.

Fijałkowski D. 1994. Flora roślin naczyniowych Lubelszczyzny (I). Lub. Tow. Nauk., Lublin.

Fij a ł kow sk i D. 1996. Ochrona przyrody i środowiska naturalnego w środkowowschodniej Polsce. UMCS, Lublin. 
Fijałkowski D, Lorens B. 1998. Rośliny borealne we florze Lubelszczyzny. / Boreal plants in flora of Lublin Region. Ann. UMCS, sect. C, 53: 61-71.

Fijałkowski D, Izdebski K. 2002. Flora Poleskiego Parku Narodowego - Flora Naczyniowa. [W:] Radwan S. (red.), Poleski Park Narodowy monografia przyrodnicza. / Polesie National Park - Vascular Flora. In: Radwan S. (ed.), Polesie National Park - Natural Monograph. Wyd. Morpol, Lublin, 103-114.

Jasnowska J., Jasnowski M. 1977. Zagrożone gatunki flory torfowisk./ Endangered plant species of peat-bogs. Chrońmy Przyr. Ojcz. 4: 5-14.

Ka c N. J. 1975. Bagna kuli ziemskiej. Wyd. PWN, Warszawa.

K r uszeln i ck i J. 2001. Salix lapponum L. (wierzba lapońska). [W:] Kaźmierczakowa R., Zarzycki K. (red.) 2001. Polska Czerwona Księga Roślin. Paprotniki i rośliny kwiatowe. Instytut Botaniki PAN, Kraków.

Mat us zki ew ic z W. 2005. Przewodnik do oznaczania zbiorowisk roślinnych Polski. Wyd. Nauk. PWN, Warszawa.

Michalczyk Z. 1991. Stosunki wodne Pojezierza Łęczyńsko-Włodawskiego. Wody powierzchniowe. / Water relations of the Łęczyńsko-Włodawskie Lakeland. Surface waters. [In:] Kleczkowski A. S. (ed.). Studia Ośrodka Dokumentacji Fizjograficznej. PAN, Wrocław, Warszawa, Kraków, 19: 41-48.

Michalczyk Z., Turczyński M. 1998. Przekształcenia i zagrożenia hydrosfery. / Transformations and threats to the hydrosphere. [In:] Harasimiuk M., Michalczyk., Turczyński M. (ed.), Jeziora łęczyńsko-włodawskie. Monografia przyrodnicza. Biblioteka Monitoringu Środowiska, Lublin: 157-164.

Mirek Z., Piękoś-Mirkowa H., Zając A., Zając M. 2002. Flowering plants and Pteridophytes of Poland. A checklist. Inst. Botaniki PAN, Kraków.

Nowicka-Falkowska K. 2002. Flora naczyniowa jeziora Karaśne w Poleskim Parku Narodowym. [W:] Radwan S., Gliński J., Geodecki M., Rozmus M. (red.), Środowisko Przyrodnicze Polesia - stan aktualny i zmiany. Cz. III / The Vascular Flora of Karaśne Lake in Polesie National Park. In: Radwan S., Gliński J., Geodecki M., Rozmus M. (ed.), Natural Environment of Polesie - Current Condition and Changes. Acta Agrophysica, 68: 159-167.

Piękoś-Mirkowa H., Mirek Z. 2003. Atlas roślin chronionych. Ofic. Wyd. MULTICO, Warszawa.

Podbielkowski Z., Tomaszewicz H. 1977. O ochronę torfowiska z wierzbą lapońską Salix lapponum na Pojezierzu Sejneńskim. / For the protection of the peat bog with downy willow, Salix lapponum, in the Sejneńskie Lakeland. Chrońmy Przyr. Ojcz. 4: 67-68.

Podbielkowski Z. 2002. Fitogeografia części świata. Tom I. Europa, Azja, Afryka. Wyd. Nauk. PWN. Warszawa.

Pogorzelec M. 2008. Influence of Chosen Environmental Abiotic Factors on Salix lapponum L. Populations in Polesie Lubelskie Region. Polish J. Environ. Stud. 17, 4: 581-586.
Rutkowski L. 1998. Klucz do oznaczania roślin naczyniowych Polski niżowej. Wyd. Nauk. PWN, Warszawa.

Sołtys M., Różycki A. 1996. Rzadkie i zagrożone gatunki flory naczyniowej w Poleskim Parku Narodowym. [W:] Radwan S. (red.), Funkcjonowanie ekosystemów wodno-błotnych w obszarach chronionych Polesia. I Rare and Endangered Vascular Plant Species in Polesie National Park. In: Radwan S. (ed.), Wetlands Ecosystems Functioning in the Protected Areas of Polesie. Wyd. UMCS, Lublin, 89-95.

Turczyński M., Michalczyk Z., Bartoszewski S. 2000. Geograficzne aspekty ochrony i użytkowania hydrosfery Pojezierza Łęczyńsko-Włodawskiego. / Geographical aspects of protection and use of the hydrosphere of the Łęczyńsko-Włodawskie Lakeland. [In:] Radwan S., Lorkiewicz Z. (ed.). Problemy ochrony i użytkowania obszarów wiejskich o dużych walorach przyrodniczych. Publ. UMCS, Lublin: 57-61.

U rba n D., G awlik J. 2003. Stopień zróżnicowania zbiorowisk roślinnych w różnych typach torfowisk [W:] Radwan S. (red.), Przyrodnicze podstawy ochrony i odnowy ekosystemów wodno-torfowiskowych w obszarze funkcjonalnym Poleskiego Parku Narodowego na tle antropogenicznych przekształceń środowiska przyrodniczego. Rozprawy i monografie. / The Degree of the Plant Communities Differentiation in Different Types of Peat-bogs. In: Radwan S. (ed.), The Natural Bases of the Boggy Ecosystems Protection and Renovation in the Functional Area of Polesie National Park, on the Background the Anthropogenic Transformations of Natural Environment. Acta Agroph. 91: 166-178.

Urban D., Wawe r M. 2001. Salix lapponum L. i S. myrtilloides L. w okolicach Sobiboru na Pojezierzu Łęczyńsko-Włodawskim. / Salix lapponum L. i S. myrtilloides L. in the Area of Sobibór in the Łęczyńsko-Włodawskie Lake District. Ann. UMCS, 56 (11): 83-93.

W i 1 g a t T. 1991. Stosunki wodne Pojezierza Łęczyńsko-Włodawskiego. Zmiany stosunków wodnych pod wpływem gospodarki. / Water relations of the Łęczyńsko-Włodawskie Lakeland. Economy-driven changes in water relations. [In:] Kleczkowski A. S. (ed.). Studia Ośrodka Dokumentacji Fizjograficznej. PAN, Wrocław, Warszawa, Kraków, 19: 48-52.

Wojciechowski I., Fijałkowski D. 1998. Plan Ochrony Poleskiego Parku Narodowego. Operat ochrony i kształtowania ekosystemów lądowych, Cz.II. Zespoły torfowiskowe. / Plan for Protection of Polesie National Park. Statement of protection and shaping the land ecosystems, Part II. Peat bog communities. Manuscript in Polesie National Park, Urszulin.

Wy s o ck i Cz., Sikorski P. 2002. Fitosocjologia stosowana. Wyd. SGGW. Warszawa.

Zarzycki K., Trzcińska-Tacik H., Różański W., Szeląg Z., Wołek J., Korzeniak U. 2002. Ecological indicator values of vascular plants of Poland. W. Szafer Institute of Botany, Polish Academy of Science, Kraków. 


\section{Wierzba lapońska (Salix lapponum L.) jako składnik różnych fitocenoz Poleskiego Parku Narodowego}

\section{Streszczenie}

Celem pracy była waloryzacja aktualnych stanowisk gatunku reliktowego Salix lapponum na terenie Poleskiego Parku Narodowego, określenie liczebności i kondycji populacji wierzby lapońskiej oraz analiza warunków biocenotycznych w jej stanowiskach.

Badania przeprowadzone w latach 2001-2003 pozwoliły stwierdzić, że znacznie zmalała liczba stanowisk $S$. lapponum, a liczebność jej populacji w potwierdzonych stanowiskach w Poleskim Parku Narodowym jest znacznie mniejsza niż przed 50. laty.

Salix lapponum była składnikiem różnych fitocenoz, ale największą jej liczebność i wysoki stopień dorodności zanotowano w stanowiskach ze zbiorowiskami Betulo-Salicetum repentis i Thelypteridi-Phragmitetum. Charakter fitocenoz, w których najliczniej występowała Salix lapponum może świadczyć o szerokim zakresie tolerancji wierzby lapońskiej w stosunku do warunków siedliskowych.

Istnieje prawdopodobieństwo, że nie tylko zmiana warunków siedliskowych, jakie odnotowano w ostatnim półwieczu miała istotny wpływ na zmniejszanie się liczby stanowisk i liczebności populacji gatunku. Istotnym problemem jawi się fakt braku kwitnienia osobników w wielu badanych populacjach, czego wynikiem może być niedostateczny stopień dostosowania S. lapponum do zmieniających się warunków środowiska. 